\title{
Hazards Analysis Report Addendum Building 518/518A Industrial Gases \& Chemtrack Receiving \& Barcoding Facility
}

\author{
R. D. Hickman
}

February 4, 2000

U.S. Department of Energy

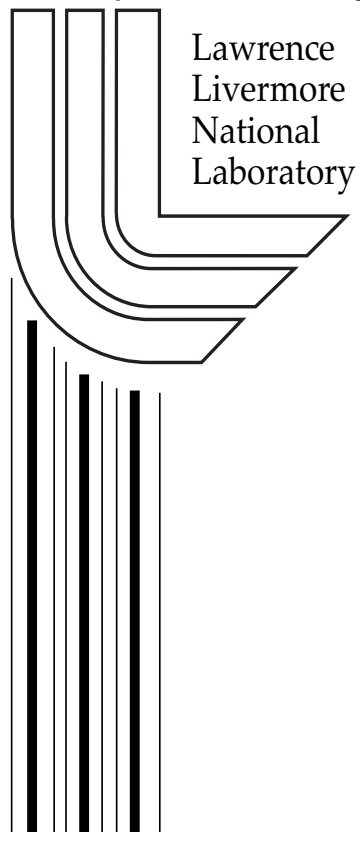




\section{DISCLAIMER}

This document was prepared as an account of work sponsored by an agency of the United States Government. Neither the United States Government nor the University of California nor any of their employees, makes any warranty, express or implied, or assumes any legal liability or responsibility for the accuracy, completeness, or usefulness of any information, apparatus, product, or process disclosed, or represents that its use would not infringe privately owned rights. Reference herein to any specific commercial product, process, or service by trade name, trademark, manufacturer, or otherwise, does not necessarily constitute or imply its endorsement, recommendation, or favoring by the United States Government or the University of California. The views and opinions of authors expressed herein do not necessarily state or reflect those of the United States Government or the University of California, and shall not be used for advertising or product endorsement purposes.

This work was performed under the auspices of the U. S. Department of Energy by the University of California, Lawrence Livermore National Laboratory under Contract No. W-7405-Eng-48.

This report has been reproduced directly from the best available copy.

Available electronically at http://www.doc.gov/bridge

Available for a processing fee to U.S. Department of Energy

And its contractors in paper from

U.S. Department of Energy

Office of Scientific and Technical Information

P.O. Box 62

Oak Ridge, TN 37831-0062

Telephone: (865) 576-8401

Facsimile: (865) 576-5728

E-mail: reports@adonis.osti.gov

Available for the sale to the public from

U.S. Department of Commerce

National Technical Information Service

5285 Port Royal Road

Springfield, VA 22161

Telephone: (800) 553-6847

Facsimile: (703) 605-6900

E-mail: orders@ntis.fedworld.gov

Online ordering: http://www.ntis.gov/ordering.htm

OR

Lawrence Livermore National Laboratory

Technical Information Department's Digital Library

http:/ / www.llnl.gov/tid/Library.html 


\title{
HAZARDS ANALYSIS REPORT
}

\author{
ADDENDUM
}

Building 518/518A

INDUSTRIAL GASES \& CHEMTRACK RECEIVING \& BARCODING FACILITY

\author{
Hazards Control Department \\ February 4, 2000
}


Building 518 \& 518A

\section{INDUSTRIAL GASES \& CHEMTRACK RECEIVING \& BARCODING FACILITY}

\section{Directorate: Business Operations}

\section{Prepared by \\ Hazards Control Department}

$\begin{array}{lll}\text { Prepared by } & \text { February 4, } 2000 \\ \text { Reviewed by } & \text { Richard D. Hickman } \\ \text { Sefior Safety Analyst } \\ \text { Reviewed by }\end{array}$




\section{Hazards Analysis Report (HAR) Addendum for Buildings $518 / 518 \mathrm{~A}$}

\section{Table of Contents}

Executive Summary

Pg. No.

$1.0 \quad$ Introduction

1

2.0 Hazards Analysis and Classification

1

$2.1 \quad$ Inventories

2

2.1.1 Chemical Inventories $\quad 2$

2.2 Initial Hazard Classification on the Basis of Inventories 2

2.3 Bounding Accident Selection and Analysis 2

2.3.1 Methodology 3

2.3.2 Bounding Accident Selection 3

2.4 Final Hazard Classification 3

3.0 References 4

Appendix A: Screened Chemtrack Listing A-1 


\section{Executive Summary}

This is a Hazards Analysis Report (HAR) Addendum to the PHA that was issued 11/11/95 for Buildings 518/518A. A copy of that PHA is attached to this Addendum.

The November, 1995, PHA concluded that the B518 and B518A operations involved only hazards of a type and magnitude routinely encountered and accepted by the public. The term "routinely encountered and accepted by the public" came from the 1988 version of Health and Safety Manual Supplement 6.06 which was the "Safety Analysis Guide" at that time. In 1999, Supplement 6.06 was updated to account for newer DOE Orders and Directives. The referred to terminology in the 1999 version of Supplement 6.06 is operations involving hazards that are routinely "performed" by the public.

The purpose of this HAR Addendum then is to demonstrate that all of the operations currently performed at B518/B518A are routinely "performed" by the public; thus the hazard classification of GENERAL INDUSTRY is appropriate for B518/B518A.

Based on the materials and operations described in this report, Buildings 518 and $518 \mathrm{~A}$ are classified as GENERAL INDUSTRY in accordance with the requirements of (LLNL, 1999) and (DOE, 1992a). The methodology used to arrive at this classification is that described in the approach for classification on the basis of hazardous materials currently used at the Lawrence Livermore National Laboratory (LLNL, 1995). The classification was assigned by comparing estimated maximum facility inventories of chemicals to screening quantities. Other existing hazards such as high voltage electricity are controlled by OSHA regulations through the LLNL safety programs.

The classification of GENERAL INDUSTRY relies on the fact that administrative controls will prevent inventories from exceeding the maximum values used in this analysis. Changes in operations, maximum inventories, materials, or release potential that could result in the bounding consequences being exceeded, or that could negatively impact the safety of the facility, will necessitate a re-evaluation of the classification. NOTE: The current method for evaluating changes (i. e. changed experiments, chemicals, procedures, operations, etc.) for GENERAL INDUSTRY facilities is to complete an Integration Worksheet to determine if further safety analysis is required. Contact the Safety Analysis Discipline at 2-3981, or the Safety Analysis Technical Leader at 2-5263 for assistance. 


\section{Hazards Analysis Report Addendum}

\subsection{Introduction}

This report documents the Hazards Analysis Report (HAR) Addendum for Buildings 518 and 518A. In summary, the description of the facility and the operations given in the 1995 PHA are the same as the present in this year 2000. The hazards description also remains the same. The hazards analysis in this HAR Addendum is different in that it needs to be compared to operations routinely "performed" by the public.

The HAR Addendum characterizes the level of intrinsic potential hazards associated with a facility and provides the basis for hazard classification. The hazard classification determines the level of safety documentation required and the DOE Order governing the safety analysis. The hazard classification also determines the level of review and approval required for the safety analysis.

This facility does not contain any safety class systems or systems important to safety as defined in Department of Energy standard DOE-STD-3009-94.

The hazards of primary concern associated with B518 and B518A are chemical in nature. The hazard classification is determined by comparing facility inventories of chemicals with threshold values for the various hazard classification levels. In this way, the hazard level of the facility can be ascertained. The most significant hazards that could affect people in the local area of B518 and B518A, elsewhere on the LLNL site, and off site, are associated with hazardous and toxic materials. These hazards are the focus of this report and are the basis for the facility hazard classification.

\subsection{Hazards Analysis and Classification}

This HAR Addendum was performed to determine the hazard classification of B518 and B518A as per DOE Order 5480.23 (DOE, 1992a), and those elements of DOE/SAN MD 5481.1A included in the LLNL Worksmart Standards set (LLNL, 1999). The HAR Addendum is based on the approach for material hazard classification currently employed at LLNL and summarized in (LLNL, 1995), an LLNL internal document.

This section provides the basis for the evaluation and describes how the hazard classification was derived for B518 and B518A. In summary it covers the following:

- A comparison of facility inventories of chemicals to threshold values, resulting in the hazard classification

Administrative controls and operational restrictions are in place so that maximum inventories will not exceed those provided in this analysis. If there are operational changes or changes in maximum inventories of chemicals, a re-evaluation of the facility (e.g. completion of an Integration

Worksheet or IWS) for the purpose of hazard classification would be required. 


\subsection{Inventories}

This section documents the maximum expected inventories of hazardous materials at B518 and B518A.

\subsubsection{Chemical Inventories}

The Code of Federal Regulations ( 40 CFR 302) and (40 CFR 355) list hazardous chemicals and their reportable quantities (RQs). Many of the chemicals in the inventory either are not listed in the CFRs or have relatively high RQ limits, and since the chemical quantities in the B518 and B518A facilities are generally well below these thresholds, many of these items could be screened out for the purpose of hazard classification.

The screening comparison of chemicals resulted in the modified Chemtrack included herein as Appendix A. The complete Chemtrack for B518 and B518A is available (contact the PHA preparer, R. D. Hickman).

None of the chemicals are present at or above their RQ threshold.

\subsection{Initial Hazard Classification on the Basis of Inventories}

Hazard classification on the basis of chemicals utilizes an approach where inventories are compared to threshold values. For low hazard facilities, thresholds that distinguish between a GENERAL INDUSTRY and a LOW hazard facility, are based on the Reportable Quantities (RQs) provided in 40 CFR 302 and 40 CFR 355. As stated above, none of the chemicals in B518 or B518A are above their RQ thresholds. Therefore; on the basis of inventories, B518 and B518A are classified GENERAL INDUSTRY hazard.

\subsection{Bounding Accident Selection and Analysis}

In this section, accidents are postulated to bound the consequences of releases of the more hazardous chemicals at B518 and B518A. Radionuclide releases are not considered since there are no radionuclides in B518 or B518A. 


\subsubsection{Methodology}

Consequences of the bounding accidents are determined by developing source terms consistent with conditions of the accidents and then evaluating the impacts using standard dispersion codes. For a hazard analysis report or HAR Addendum, a worst case approach is used and utilizes computer programs such as ALOHA (EPA/NOAA) and EPIcode (Homann, S, 1988). These codes contain libraries with over 600 chemical substances and the capability to calculate for other substances.

The airborne concentrations of emitted substances near the source are less from a release due to a fire scenario than the zero or ground level release assumed for the ALOHA and EPIcode calculations due to the elevated release (plume rise). Also, combustion byproducts from ordinary building materials are generally considered to be hazardous and fire responders are protected accordingly. Therefore a fire scenario need not be considered in this analysis (see SARA 97-31).

The postulated bounding accident is normally the breach of any single container due to an earthquake or due to a handling error, with the subsequent spill and release of the entire contents of the container. The release is assumed to occur outdoors (i.e. a "parking lot" release) with no credit taken for holdup or dilution.

\subsubsection{Bounding Accident Requirement}

The gas yard receives and stores cylinders of various sizes and containing individual pure gases and cylinders containing mixtures of gases. These cylinders are off-loaded from delivery trucks, placed in open-air storage stalls with a metal roof, and transported to end-users. During all of these functions, a protective cap is securely screwed onto the cylinder top, and this protective cap is only removed after the cylinder has been delivered to the end-user.

An October 13, 1993, letter (SARA 93-112) contains the policy on capped gas cylinders. This letter states that an accident at Building 518 during normal handling of cylinders that is severe enough to shear off the valve of a toxic gas cylinder with the protective cap in place is an incredible event with a probability of less than $1 \times 10^{-6}$ per year. The 10/13/93 letter goes on to state that, as a result of the valve shear accident being an incredible event, this type of event will not be considered in hazard classification or safety analysis as an event that needs to be analyzed for consequences.

Therefore, a release and dispersion calculation will not be done for B518. The hazard classification determined on the basis of inventory will constitute the final classification.

The operations "performed" at B518A consist of placing a barcode (similar to placing a pricing tag) on each container that is received at this facility. Clerks at Orchard Supply or Home Depot etc. routinely "perform" this same operation. The residence time for any container in B518A is less than twenty-four hours which makes the risk from natural phenomena (earthquake, tornado, flood) or external events (aircraft crash, etc.) very small. A trained and experienced operator handles each container once. Therefore, a release and dispersion calculation will not be done for B518A.

\subsection{Final Hazard Classification}

The final facility hazard classification for B518/B518A is GENERAL INDUSTRY. 


\subsection{References}

40CFR302, "Table 302.4," Environmental Protection Agency , Code of Federal Regulations, National Archives and Records Administration

40CFR355, "List of Extremely Hazardous Substances and Their Threshold Planning Quantities," Environmental Protection Agency, Code of Federal Regulations, Appendix A, National Archives and Records Administration

Craig, D. K., (1994), "Toxic Chemical Hazard Classification and Risk Acceptance Guidelines for use in D.O.E. Facilities (U)" (Nov. 16, 1994 Recommendations of the Westinghouse M\&O Subcommittee on Nonradiological Risk Acceptance Guidelines Development).

LLNL (1999), elements of DOE/SAN MD 5481.1A, paragraphs 3, 4 and Chapter I, paragraph 2e(1), (2), (3), (4), (6), and (7); LLNL Worksmart Standards Set, Contract 48, Appendix G, $(10 / 14 / 99)$

DOE, (1992a), Nuclear Safety Analysis Reports, DOE Order 5480.23, April 1992

LLNL, (1991a), Safety Analysis Guide, Health and Safety Manual, Supplement 6.06, M-010, September 1988

LLNL, (1994), Health and Safety Manual, M-010, 1994

LLNL, (1995), Hazard Classification Methodology, SARA 95-44

Craig, 1996, ERPGs and TEELs for Chemicals of Concern: Rev. 15/Abbreviated (January 4, 1999), WSMS-SAE-99-0001

SARA 97-31, Fire Scenario Calculations To Assess Analysis Methodology Conservatism, ltr. David E. Price to Richard J. Kelly, dated 29 October, 1997

DOT, (1990), 1990 Emergency Response Guidebook, DOT P 5800.5

29CFR 1910.119, "List of Highly Hazardous Chemicals, Toxins, and Reactives," OSHA, Dept. of Labor, Code of Federal Regulations, Appendix A, National Archives and Records Administration.

Homann, S, (1988), EPIcode Emergency Prediction Information, Homann Associates Inc., Fremont, CA, 1988.

EPA/NOAA, ALOHA ${ }^{\mathrm{TM}}$ (Areal Locations of Hazardous Atmospheres) 5.0, Theoretical

Description, National Oceanic and Atmospheric Administration, August, 1992 


\section{Appendix A Screened Chemtrack Listing}

The screened Chemtrack listing for the chemicals reported in ChemTrack listings for buildings 518/518A, sorted alphabetically, is presented here. The full Chemtrack for buildings $518 / 518 \mathrm{~A}$ is in R. D. Hickman's files. Section 2.1.1 in the body of this PHA provides a description of the screening process used to arrive at this screened Chemtrack listing for B518/518A. 


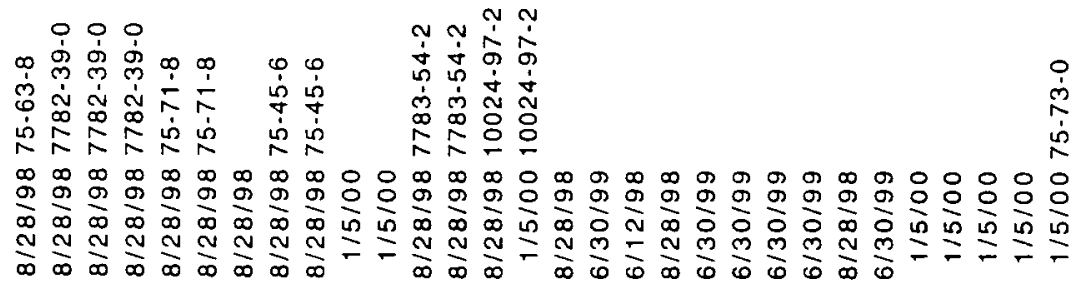

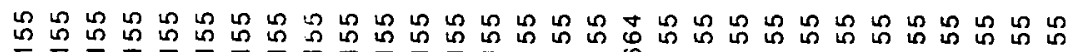

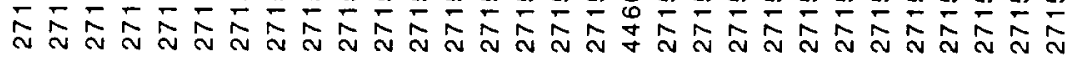

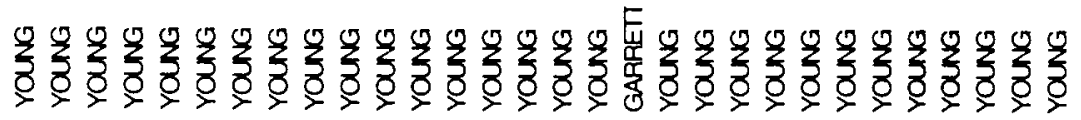

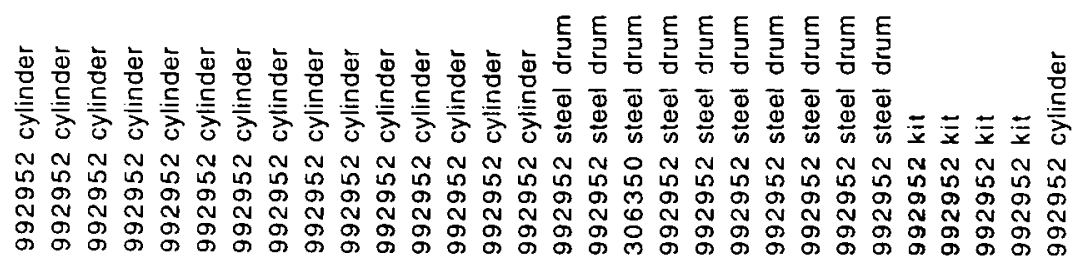

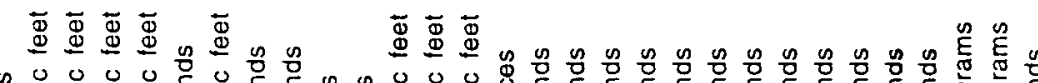

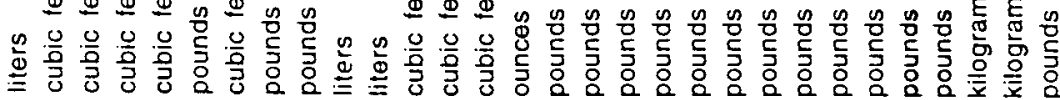

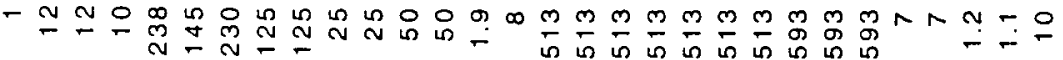

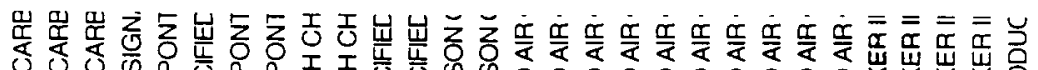
80

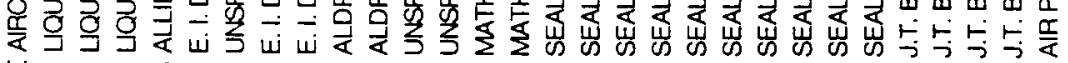

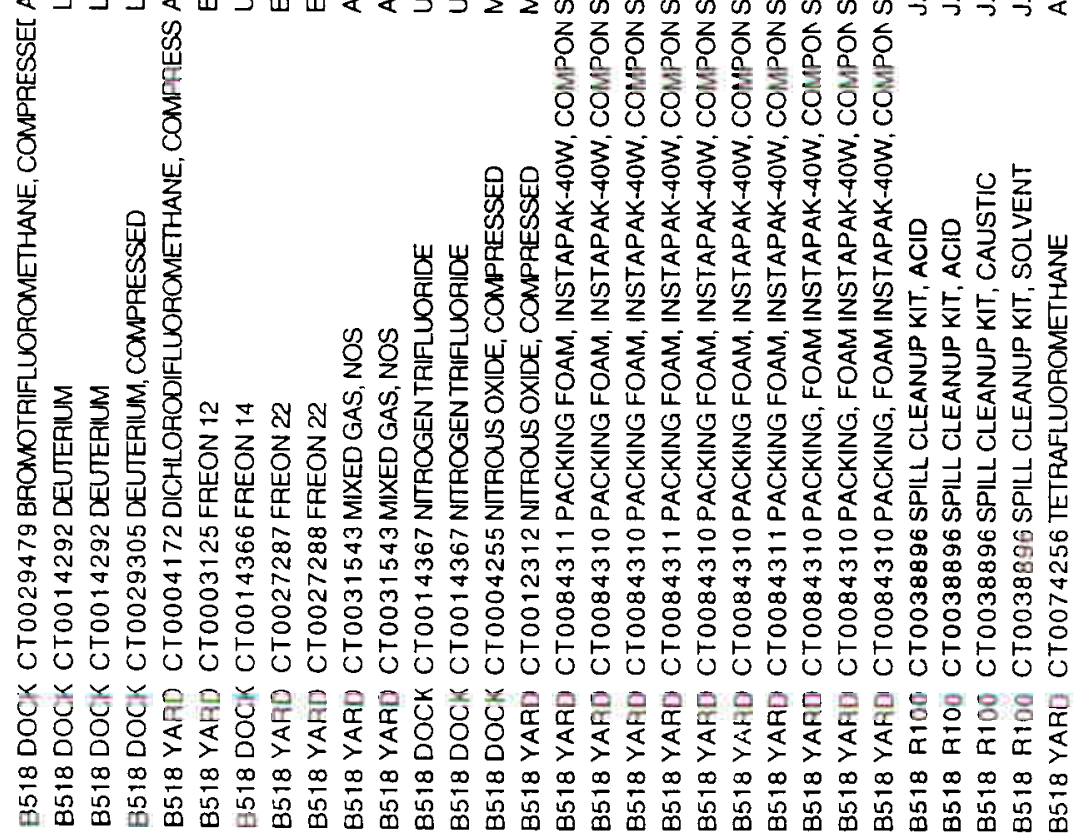

